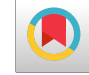

\title{
Poisoning with Atropa Belladonna in Childhood
}

\author{
Yunus Yilmaz, ${ }^{1,}$ Fatih Kara, ${ }^{2}$ Sergulen Aydin, ${ }^{3}$ Hatice Kose Ozlece, ${ }^{4}$ Serpil Can, ${ }^{5}$ and Sefer Ustebay ${ }^{1}$ \\ ${ }^{1}$ Department of Pediatrics, Medical Faculty, Kafkas University, Kars, Turkey \\ ${ }^{2}$ Department of Biochemistry, Kars State Hospital, Kars, Turkey \\ ${ }^{3}$ Department of Family Medicine, Medical Faculty, Kafkas University, Kars, Turkey \\ ${ }^{4}$ Department of Neurology, Medical Faculty, Kafkas University, Kars, Turkey \\ ${ }^{5}$ Department of Physiology, Medical Faculty, Kafkas University, Kars, Turkey \\ "Corresponding author: Yunus Yilmaz, Department of Pediatrics, Medical Faculty, Kafkas University, Kars, Turkey. Tel: +90-5069090995, Fax: +90-4742251193, E-mail: \\ dr_yilmaz36@hotmail.com
}

Received 2016 July 12; Accepted 2018 February 20.

\begin{abstract}
Background: Intoxication with Atropa belladonna is endemic in Eastern Anatolia especially in springtime. However, in literature, there are no much studies about Atropa belladonna intoxication in childhood.

Objectives: This study examines clinical and laboratory findings of pediatric Atropa belladonna intoxication cases.

Methods: Hospital official database was searched for international classification of diseases code of intoxication. The inclusion criteria included individuals under the age of 15 and who had a history of Atropa belladonna ingestion.

Results: The most frequent clinical findings were mydriasis, flushing, and meaningless speech. There was a significant rise in the white blood cell count, glucose, aspartate aminotransferase, and C - reactive protein levels.

Conclusions: Atropa belladonna intoxication clinically causes anticholinergic syndrome and can result in deteriorations in some laboratory tests.
\end{abstract}

Keywords: Atropa Belladonna, Plant Poisoning, Children.

\section{Background}

The clinical picture of symptoms and signs that break out if a toxic material is ingested is named as "intoxication". Approximately $80 \%$ of intoxications are accidental. Although all age groups are candidates for intoxication, it is more common and mortal, especially for children aged 1 - 5. While household chemicals, pesticides, hydrocarbons, drugs, and plants are mostly responsible for childhood intoxications all around the world; drugs (43.4\%) and vegetation and/or plants (21.8\%) are the most common causative agents in Turkey $(1,2)$.

Atropa belladonna, known as "deadly nightshade" in folk terminology, is a poisonous plant that grows in nature (3). This plant, which belongs to Solanaceae family, contains intensely alkaloids such as atropine, scopolamine, and hyoscyamine in its leaves, roots, and fruits $(2,4)$. It is already recorded in the literature that active substances like atropine, which cause anticholinergic intoxication establish a clinical picture of symptoms and signs including agitation, hallucinations, mydriasis, ataxia, urinary retention, delirium, flushing, and tachycardia $(5,6)$. Plasma levels of atropine may be useful in confirming the cause of intoxication (7). However, there is not much recording about labo- ratory findings of patients intoxicated by these substances. In this study, clinical and laboratory findings of 174 pediatric patients are examined.

\section{Methods}

This retrospective study includes 174 patients who consulted to the pediatric emergency department of our hospital for Atropa belladonna intoxication between 2006 2013. This study has been ethically approved by administration of our hospital (02.10.2014 - 42288353/8213). Written informed consent was not obtained from patients due to the retrospective nature of our study. Hospital official database was searched for international classification of diseases (ICD) code of intoxication. The inclusion criteria included individuals under the age of 15 and had history of Atropa belladonna ingestion. Patients who had any acute or chronic disease, had atropa belladonna intoxication, and who were using medication for chronic disorders were excluded from the study. All included patients (100 males, 74 females) were screened for clinical and laboratory findings, including complete blood cells count (CBC) and biochemical parameters. A clinical chemical analyzer device (Architect c8000; Abbott Diagnostics, Copenhagen, Den- 
mark) was used for measurement of biochemical parameters (glucose, urea, creatinine, sodium, potassium, calcium, chloride, aspartate aminotransferase (AST), alanine aminotransferase (ALT), total bilirubin (TBIL), direct bilirubin (DBIL), C-reactive protein (CRP), while an auto hematology analyzer (BC - 5800; Mindray Bio - Medical Electronics Co. Ltd., Shenzhen, China) was used for $\mathrm{CBC}$ analysis. The patients were categorized into 2 groups, mild/moderate and severe intoxication according to his/her clinical situation and patients with encephalopathy were accepted as severe intoxication (5). Also, these were classified into 3 age groups: 2 - 5, $6-10$, and $11-14$ years.

IBM SPSS Statistics 20 (SPSS Inc., Chicago, IL, USA) was used for statistical analyses. Descriptive statistic was performed to define the main features of the data in the study and Pearson Chi - Square was used for categorical variables.

\section{Results}

A total of 174 patients (100 males (57.5\%) and 74 females $(42.5 \%))$ had a mean age of $5.5 \pm 2.81$ years and age range of 2 - 14 years. Of the study group, 104 (59.8\%) were 2 - 5 years old, 60 (34.5\%) 6 - 10 years old, and 10 (5.7\%) 11 - 14 years old. The most common clinical and laboratory findings according to age groups have been given in Table 1.

There was a significant difference in sex; mild/moderate intoxication was more frequent in females and severe intoxication in male. Hyperthermia, tachypnea, tachycardia, and convulsion were more common in the severe intoxication group than in the mild/moderate group. However, ataxic gait was more often in the mild/moderate group (Table 2).

Leukocytosis in 60 patients, increased AST levels in 25 patients, increased CRP levels in 22 patients, hyperglycemia in 21 patients, decreased mean platelet volume (MPV) in 20 patients, hypercalcemia in 19 patients, and thrombocytosis in 14 patients were seen in our study. The frequency of hyperglycemia and thrombocytosis was significantly higher in the severe intoxication group as compared to the mild/moderate group (Table 3 ).

None of patients were needed for the treatment in tertiary intensive care unit or died.

\section{Discussion}

According to our study, atropa belladonna intoxication was more common among boys than girls and also more severe; the cause of which may be that the boys often play around rural areas of villages. We found that children, especially aged 2 - 5 years, were at risk of atropa belladonna intoxication, which may be attributed to that children in
Table 1. The Most Common Clinical and Laboratory Findings Among Atropa Belladonna Intoxication Cases According to Age Groups

\begin{tabular}{|c|c|c|c|}
\hline \multirow[t]{2}{*}{ Parameters } & \multicolumn{3}{|c|}{ Age Groups } \\
\hline & $\begin{array}{c}2 \text { - } 5 \text { Years, } \mathbf{N} \\
(\%)\end{array}$ & $\begin{array}{c}6 \text { - } 10 \text { Years, } \\
N(\%)\end{array}$ & $\begin{array}{c}11 \text { - } 14 \text { Years, } \\
\mathrm{N}(\%)\end{array}$ \\
\hline \multicolumn{4}{|l|}{ Clinical findings } \\
\hline Aggression & $95(54.6)$ & $49(28.2)$ & $4(2.3)$ \\
\hline Headache & $1(0.6)$ & $1(0.6)$ & $1(0.6)$ \\
\hline $\begin{array}{l}\text { Meaningless } \\
\text { speech }\end{array}$ & $101(58.1)$ & $58(33.3)$ & $7(4.0)$ \\
\hline Vomiting & $3(1.7)$ & $2(1.2)$ & $0(0)$ \\
\hline Hyperthermia & $20(11.5)$ & $8(4.6)$ & $1(0.6)$ \\
\hline Tachypnea & $5(2.9)$ & $2(1.2)$ & $0(0)$ \\
\hline Agitation & $97(55.8)$ & $56(32.2)$ & $5(2.9)$ \\
\hline Ataxic gait & $83(47.7)$ & $44(25.3)$ & $5(2.9)$ \\
\hline Dry mouth & $6(3.5)$ & $4(2.3)$ & $3(1.7)$ \\
\hline Flushing & $101(58.1)$ & $58(33.3)$ & $8(4.6)$ \\
\hline Lethargy & $3(1.7)$ & $0(0)$ & $0(0)$ \\
\hline Mydriasis & $103(59.2)$ & $58(33.3)$ & $8(4.6)$ \\
\hline Tachycardia & $95(54.6)$ & $51(29.3)$ & $2(1.2)$ \\
\hline Convulsion & $4(2.3)$ & $1(0.6)$ & $0(0)$ \\
\hline \multicolumn{4}{|l|}{ Laboratory findings } \\
\hline Hyperglycemia & $12(6.9)$ & $8(4.6)$ & $1(0.6)$ \\
\hline Hyponatremia & $3(1.7)$ & $4(2.3)$ & $0(0)$ \\
\hline Hypercalcemia & $12(6.9)$ & $5(2.9)$ & $2(1.2)$ \\
\hline Increased AST & $20(11.5)$ & $4(2.3)$ & $1(0.6)$ \\
\hline Increased CRP & $15(8.6)$ & $7(4.0)$ & $0(0)$ \\
\hline Leukocytosis & $42(24.1)$ & $15(8.6)$ & $3(1.7)$ \\
\hline Thrombocytosis & $13(7.5)$ & $1(0.6)$ & $0(0)$ \\
\hline Decreased MPV & $16(9.2)$ & $4(2.3)$ & $0(0)$ \\
\hline
\end{tabular}

AST: aspartate aminotransferase; CRP: c - reactive protein; MPV: mean platelet volume.

this age group are more curiosity to know the environment.

In our study, the most common clinical findings included mydriasis (97.1\%), flushing (95.9\%), meaningless speech (95.4\%), agitation (90.8\%), aggression (85.1\%), tachycardia (85.1\%), and ataxic gait (75.9\%), which is in agreement with previous studies $(3,5)$. Hyperthermia, tachypnea, tachycardia, and convulsion were seen more often in the severe intoxication group, while ataxic gait in the mild/moderate group. Atropa belladonna - induced hyperthermia may be due to both inhibition of sweat gland activity and stimulation of temperature centre in the hypothalamus. Children are especially susceptible to atropine fever, which may be seen even at subtherapeutic doses in children (8).

Significant laboratory findings were as following: 
Table 2. Clinical Findings Among Atropa Belladonna Intoxication Cases

\begin{tabular}{|c|c|c|c|c|}
\hline Parameters & Children with Mild/Moderate Intoxication, $(\mathrm{N}=94)$ & Children with Severe Intoxication, $(\mathrm{N}=\mathbf{8 0})$ & $\mathrm{X}^{2}$ & $\mathbf{P}$ \\
\hline Sex & $\mathrm{N}(\%)$ & $\mathrm{N}(\%)$ & & \\
\hline Boy & $41(43.6)$ & $59(73.7)$ & & \\
\hline Girl & $53(56.4)$ & $21(26.3)$ & 16.055 & 0.000 \\
\hline Symptoms & $\mathrm{N}(\%)$ & $\mathrm{N}(\%)$ & & \\
\hline Aggression & $76(80.9)$ & $72(90.0)$ & 2.846 & 0.092 \\
\hline Headache & $2(2.1)$ & $1(1.3)$ & 0.196 & 0.658 \\
\hline Meaningless speech & $88(93.6)$ & $78(97.5)$ & 1.486 & 0.223 \\
\hline Vomiting & $4(4.3)$ & $1(1.3)$ & 1.399 & 0.237 \\
\hline Signs & $\mathrm{N}(\%)$ & $\mathrm{N}(\%)$ & & \\
\hline Hyperthermia & $7(7.4)$ & $22(27.5)$ & 12.513 & 0.000 \\
\hline Tachypnea & $1(1.1)$ & $6(7.5)$ & 4.637 & 0.031 \\
\hline Hypotension & 0 & 0 & & \\
\hline Hypertension & 0 & 0 & & \\
\hline Agitation & $88(93.6)$ & $70(87.5)$ & 1.937 & 0.164 \\
\hline Ataxic gait & $81(86.2)$ & $51(63.8)$ & 11.864 & 0.001 \\
\hline Dry mouth & $6(6.4)$ & $7(8.8)$ & 0.350 & 0.554 \\
\hline Flushing & $91(96.8)$ & $76(95.0)$ & 0.366 & 0.545 \\
\hline Lethargy & $0(0)$ & $3(3.8)$ & 3.587 & 0.058 \\
\hline Mydriasis & $91(96.8)$ & $78(97.5)$ & 0.074 & 0.786 \\
\hline Tachycardia & $74(78.7)$ & $74(92.5)$ & 6.454 & 0.011 \\
\hline Convulsion & $0(0)$ & $5(6.3)$ & 6.049 & 0.014 \\
\hline
\end{tabular}

leukocytosis (34.5\%), increased AST (14.4\%), increased CRP (12.6\%), hyperglycemia (12.1\%), decreased MPV (11.5\%), hypercalcemia (10.9\%), and thrombocytosis (8.1\%). Laboratory findings in poisoning with Atropa belladonna are contradictory in existing literature. Trabattoni et al., (9) reported a case (68 - year - old man) with Atropa belladonna poisoning, who had a blood glucose level of $130 \mathrm{mg} / \mathrm{dL}$; however, his leukocyte count was normal. Whereas, some case reports showed that laboratory workup was unremarkable except for leukocytosis in such intoxications $(10,11)$. In another case, all the laboratory results were normal (12). Nonetheless, the studies generally propose that it may be an increase in glucose $(5,9,13,14)$, AST (5), ALT (7), and CRP (15) levels and white blood cell (WBC) count (5, 7, 10, 11, 13, 14). In a comprehensive study, Caksen et al., (5) reported an analysis of 49 children. In this study, laboratory examination revealed leukocytosis in 3 children, hyperglycemia in 17 children, and elevated AST level in 4 children. The results of our study generally agree with the literature. Agarwal et al., (11) suggested that Atropa belladonna poisoning can mimic septicemia because of high WBC count and some other clinical signs. There was an important increase in CRP and WBC in our research. Therefore, we recommend that Atropa belladonna poisoning must be taken into ac- count in differential diagnosis of children with leukocytosis. Berdai et al., (16) reported a case of intoxication with Atropa belladonna in a child and declared that routine full blood count as well as renal and liver function tests revealed hepatic cytolysis; however, the finding may be due to hepatic side effect of antituberculosis treatment in this case. In our study, there was significant rise in only AST levels. Due to the fact that liver function tests (ALT, TBIL, DBIL), other than AST, were normal, this rise in AST levels cannot be attributed to liver dysfunction, in our opinion. Renal function tests (urea, creatinine) were also found normal. Based on these results, we can say that active substances in Atropa belladonna do not effect liver and kidney functions. We found that hyperglycemia and thrombocytosis were more common in the severe intoxication group than the mild/moderate intoxication group, which strongly suggests that there may be a causal relationship between atropa belladonna poisoning and these laboratory findings. However, further studies are required for a better understanding of the mechanism. Hypercalcemia was present in $10.9 \%$ of the cases in our study. Three organs participate in calcium homeostasis: (a) the small intestine, where dietary calcium is absorbed, (b) the skeleton as a calcium reservoir, and (c) the kidney, where calcium is reab- 
Table 3. Laboratory Findings Among Atropa Belladonna Intoxication Cases

\begin{tabular}{|c|c|c|c|c|c|c|}
\hline \multirow[t]{3}{*}{ Parameters } & \multirow{2}{*}{\multicolumn{2}{|c|}{$\begin{array}{c}\text { Children with Mild/Moderate Intoxication } \\
\qquad(\mathrm{N}=94)\end{array}$}} & \multirow{2}{*}{\multicolumn{2}{|c|}{$\begin{array}{c}\text { Children with Severe Intoxication } \\
(\mathbf{N}=\mathbf{8 0})\end{array}$}} & \multirow[t]{3}{*}{$\mathrm{X}^{2}$} & \multirow[t]{3}{*}{$\mathbf{P}$} \\
\hline & & & & & & \\
\hline & $\begin{array}{l}\text { Under Range } \\
\text { Values, N(\%) }\end{array}$ & $\begin{array}{c}\text { Over Range Values, } \\
\mathbf{N}(\%)\end{array}$ & $\begin{array}{l}\text { Under Range } \\
\text { Values, N (\%) }\end{array}$ & $\begin{array}{l}\text { Over Range Values, } \\
\mathbf{N}(\%)\end{array}$ & & \\
\hline Glucose & 0 & $6(6.4)$ & 0 & $15(18.8)$ & 6.229 & 0.013 \\
\hline Creatinine & 0 & 0 & 0 & 0 & & \\
\hline Urea & 0 & 0 & 0 & 0 & & \\
\hline Sodium & $2(2.1)$ & 0 & $5(6.3)$ & 0 & 1.902 & 0.168 \\
\hline Potassium & $1(1.1)$ & $1(1.1)$ & $1(1.3)$ & $1(1.3)$ & 0.013 & 0.909 \\
\hline Chloride & 0 & $2(2.1)$ & 0 & $1(1.3)$ & 0.196 & 0.658 \\
\hline Calcium & 0 & $9(9.6)$ & 0 & $10(12.5)$ & 0.380 & 0.537 \\
\hline AST & 0 & $12(12.8)$ & 0 & $13(16.3)$ & 0.426 & 0.514 \\
\hline ALT & 0 & 0 & 0 & $1(1.3)$ & 1.182 & 0.277 \\
\hline TBIL & 0 & $1(1.1)$ & 0 & $2(2.5)$ & 0.526 & 0.468 \\
\hline DBIL & 0 & $1(1.1)$ & 0 & $2(2.5)$ & 0.526 & 0.468 \\
\hline CRP & 0 & $10(10.6)$ & 0 & $12(15.0)$ & 0.744 & 0.388 \\
\hline WBC & 0 & $27(28.7)$ & 0 & $33(41.3)$ & 3.002 & 0.083 \\
\hline Hemoglobin & $8(8.5)$ & 0 & $7(8.8)$ & 0 & 0.003 & 0.955 \\
\hline \multirow[t]{2}{*}{ Platelets } & $2(2.1)$ & $4(4.3)$ & $1(1.3)$ & $10(12.5)$ & $\begin{array}{l}3.971 \text { (for } \\
\text { thrombocytosis) }\end{array}$ & $\begin{array}{l}0.046 \text { (for } \\
\text { thrombocytosis) }\end{array}$ \\
\hline & & & & & $\begin{array}{c}0.196 \text { (for } \\
\text { thrombocytopenia) }\end{array}$ & $\begin{array}{c}0.658 \text { (for } \\
\text { thrombocytopenia) }\end{array}$ \\
\hline \multirow[t]{2}{*}{ MPV } & $9(9.6)$ & $5(5.3)$ & $11(13.8)$ & $4(5.0)$ & $\begin{array}{c}0.009 \text { (for increased } \\
\mathrm{MPV} \text { ) }\end{array}$ & $\begin{array}{l}0.925 \text { (for increased } \\
\text { MPV) }\end{array}$ \\
\hline & & & & & $\begin{array}{c}0.741 \text { (for decreased } \\
\text { MPV) }\end{array}$ & $\begin{array}{c}0.389 \text { (for decreased } \\
\text { MPV) }\end{array}$ \\
\hline
\end{tabular}

ALT: alanine aminotransferase; AST: aspartate aminotransferase; CRP: c - reactive protein; DBIL: direct bilirubin; MPV: mean platelet volume; TBIL: total bilirubin; WBC: white blood cell.

sorbed from the tubular system into blood. Intoxication induced hypercalcemia may be due to calcium efflux from the skeleton due to the fact that it can rapidly change the serum calcium levels (17). In this study, $8.6 \%$ of the patients were anemic, however, this situation cannot be attributed to the intoxication because of absence of bleeding or hyperbilirubinemia.

There is no article in the literature that presents clinical and laboratory findings on this topic with this sample size. Our study demonstrates the most common clinical findings and probable laboratory deteriorations in these cases with a large sample size. We believe that the data in this paper can illuminate and inform the clinicians on poisoning with Atropa belladonna.

\section{Footnotes}

Financial Disclosure: The authors declared that this study has received no financial support.

Conflict of Interest: No conflict of interest was declared by the authors.

\section{References}

1. Aji DY, Ilter, O . Turkiye'de cocuk zehirlenmeleri. Turk Ped Arsivi. 1998;33:154-8.

2. Lamminpaa A, Kinos M. Plant poisonings in children. Hum Exp Toxicol. 1996;15(3):245-9. doi: 10.1177/096032719601500310. [PubMed: 8839213].

3. Lange A, Toft P. [Poisoning with nightshade, Atropa belladonna]. Ugeskr Laeger. 1990;152(15):1096. [PubMed: 2330633].

4. Southgate HJ, Egerton M, Dauncey EA. Lessons to be learned: a case study approach. Unseasonal severe poisoning of two adults by deadly nightside (Atropa belladonna).J R Soc Promot Health. 2000;120(2):12730. [PubMed: 10944889].

5. Caksen H, Odabas D, Akbayram S, Cesur Y, Arslan S, Uner A, et al. Deadly nightshade (Atropa belladonna) intoxication: an analysis of 49 children. Hum Exp Toxicol. 2003;22(12):665-8. doi: 10.1191/0960327103ht4040a. [PubMed: 14992329].

6. Tulin F, Kirpinar I. Olumcul nightshade zehirlenmesi bir olguda psikiyatrik yonleri. JAEM. 2011;10:86-8.

7. Bogan R, Zimmermann T, Zilker T, Eyer F, Thiermann H. Plasma level of atropine after accidental ingestion of Atropa belladonna. Clin Toxicol (Phila). 2009;47(6):602-4. doi: 10.1080/15563650903058906. [PubMed: 19586361]. 
8. Tripathi KD. Essentials of Medical Pharmacology. 7 th ed. New Delhi: JP Medical Ltd; 2013. doi: 10.5005/jp/books/12256.

9. Trabattoni G, Visintini D, Terzano GM, Lechi A. Accidental poisoning with deadly nightshade berries: a case report. Hum Toxicol. 1984;3(6):513-6. [PubMed: 6526400].

10. Demir C, Dulger C, Mete R, Arslan S, Dilek I. Atropa belladonna ile zehirlenme: Bir olgu sunumu. Van Tip Dergisi. 2006;13(2):61-3.

11. Agarwal P, Bansal S, Sharma A, Saini VK. Atropine poisoning mimicking septicemia. Ann Neurosci. 2014;21(1):34-5. doi: 10.5214/ans.0972.7531.210111. [PubMed: 25206054].

12. Glatstein M, Danino D, Wolyniez I, Scolnik D. Seizures caused by ingestion of Atropa belladonna in a homeopathic medicine in a previously well infant: case report and review of the literature. Am J Ther. 2014;21(6):196-8. doi: 10.1097/MJT.0b013e3182785eb7. [PubMed: 24105354].

13. Ceha LJ, Presperin C, Young E, Allswede M, Erickson T. Anticholinergic toxicity from nightshade berry poisoning responsive to physostigmine. J Emerg Med.1997;15(1):65-9. [PubMed: 9017490].

14. Demirhan A, Tekelioglu UY, Yildiz I, Korkmaz T, Bilgi M, Akkaya A, et al. Anticholinergic Toxic Syndrome Caused by Atropa Belladonna Fruit (Deadly Nightshade): A Case Report. Turk J Anaesthesiol Reanim. 2013;41(6):226-8. doi: 10.5152/TJAR.2013.43. [PubMed: 27366377].

15. Laffargue F, Oudot C, Constanty A, Bedu A, Ketterer-Martinon S. [Deadly nightshade (Atropa belladonna) intoxication in a 2-year-old child]. Arch Pediatr. 2011;18(2):186-8. doi: 10.1016/j.arcped.2010.11.006. [PubMed: 21194906].

16. Berdai MA, Labib S, Chetouani K, Harandou M. Atropa belladonna intoxication: a case report. Pan Afr Med J. 2012;11:72. [PubMed: 22655106].

17. Del Valle HB, Yaktine AL, Taylor CL, Ross AC. Dietary reference intakes for calcium and vitamin D. Washington(DC): National Academies Press; 2011. 